\title{
Electrochemical promotion of NO reduction by hydrogen on a platinum/polybenzimidazole catalyst
}

Petrushina, Irina; Bandur, Viktor; Cappeln, Frederik Vilhelm; Bjerrum, Niels; Sørensen, Rasmus Zink; Refshauge, R.H.; Li, Qingfeng

Published in:

Journal of The Electrochemical Society

Link to article, DOI:

10.1149/1.1566413

Publication date:

2003

Document Version

Publisher's PDF, also known as Version of record

Link back to DTU Orbit

Citation (APA):

Petrushina, I., Bandur, V., Cappeln, F. V., Bjerrum, N., Sørensen, R. Z., Refshauge, R. H., \& Li, Q. (2003). Electrochemical promotion of NO reduction by hydrogen on a platinum/polybenzimidazole catalyst. Journal of The Electrochemical Society, 150(5), D87-D90. https://doi.org/10.1149/1.1566413

\section{General rights}

Copyright and moral rights for the publications made accessible in the public portal are retained by the authors and/or other copyright owners and it is a condition of accessing publications that users recognise and abide by the legal requirements associated with these rights.

- Users may download and print one copy of any publication from the public portal for the purpose of private study or research.

- You may not further distribute the material or use it for any profit-making activity or commercial gain

- You may freely distribute the URL identifying the publication in the public portal 


\title{
Electrochemical Promotion of NO Reduction by Hydrogen on a Platinum/Polybenzimidazole Catalyst
}

\author{
I. M. Petrushina,* V. A. Bandur, F. Cappeln, N. J. Bjerrum,,z R. Z. Sørensen, \\ R. H. Refshauge, and Qingfeng $\mathrm{Li}^{*}$ \\ Materials Science Group, Department of Chemistry, Technical University of Denmark, DK-2800 Lyngby, \\ Denmark
}

The electrochemical promotion of catalytic NO reduction by hydrogen was studied using a $\left(\mathrm{NO}, \mathrm{H}_{2}\right.$, Ar), Pt polybenzimidazole ( $\mathrm{PBI})-\mathrm{H}_{3} \mathrm{PO}_{4} \mid \mathrm{Pt},\left(\mathrm{H}_{2}, \mathrm{Ar}\right)$ fuel cell at $135^{\circ} \mathrm{C}$. A mixture of $\mathrm{NO} / \mathrm{H}_{2} / \mathrm{Ar}$ was used as the working mixture at one electrode and a mixture of $\mathrm{H}_{2}$ /Ar was used as reference and counter gas at the other electrode. Products of $\mathrm{NO}$ reduction $\left(\mathrm{N}_{2}\right.$ and $\left.\mathrm{H}_{2} \mathrm{O}\right)$ were analyzed by an on-line mass spectrometer. At high $\mathrm{NO}+\mathrm{H}_{2}+$ Ar flow rate $(17 \mathrm{~mL} / \mathrm{min} ; 17$ and $354 \mathrm{~mL} / \mathrm{min}$, respectively, at atmospheric pressure) the maximum rate enhancement ratio was 4.65. At low $\mathrm{NO}+\mathrm{H}_{2}+$ Ar flow rate $(17 \mathrm{~mL} / \mathrm{min} ; 17$ and 140 $\mathrm{mL} / \mathrm{min}$, respectively), NO reduction increased 20 times even without polarization compared to the high gas flow rate. The electrochemical promotion effect occurs at positive polarization with a maximum increase at approximately $0.08 \mathrm{~V}$ and with 1.5 times the zero polarization value. The promotion at the negative polarization can be attributed to the electrochemical production of the promoters. At low gas flow rates, a charge-induced change of the strength of chemisorptive bonds can take place.

(C) 2003 The Electrochemical Society. [DOI: 10.1149/1.1566413] All rights reserved.

Manuscript submitted August 27, 2002; revised manuscript received December 5, 2002. Available electronically March 28, 2003.

The present work is a continuation of our research in the fields of electrochemical promotion ${ }^{1}$ and polymer electrolyte fuel cells. ${ }^{2,3}$ That a catalyst is often a system which consists of an electronic and an ionic conductor makes it possible to use electrochemical techniques to study the nature of the promotion effect in catalysts. Application of galvanic cells with solid electrolytes for the study of catalytic phenomena was suggested by Wagner. ${ }^{4}$ Later, Vayenas et al. ${ }^{5}$ found that rate and selectivity of a catalytic reaction can be remarkably and reversibly changed by electrochemical polarization of the electronic conductive catalyst on an ionic conductive support. This phenomenon was named NEMCA effect (nonfaradaic electrochemical modification of catalytic activity) or electrochemical promotion. ${ }^{4}$ The NEMCA effect has been demonstrated for more then 50 heterogeneous ${ }^{2,5-22}$ and one homogeneous ${ }^{1}$ catalytic reactions. According to Vayenas et al., ${ }^{5-10}$ the NEMCA effect can be described by the following parameters.

The rate enhancement ratio

$$
\rho=r / r_{\mathrm{o}}
$$

and the enhancement factor

$$
\Lambda=\left(r-r_{\mathrm{o}}\right) /(1 / 2 F)
$$

where $r$ is the catalytic rate at current $I, r_{\mathrm{o}}$ is the open-circuit catalytic rate, and $F$ is Faraday's constant. In all studied cases of the electrochemical promotion $|\Lambda| \gg 1$ and that was the reason for this effect being called nonfaradaic.

Vayenas et al..$^{5-10}$ explained the electrochemical promotion of a catalyst as an effect of changes in the work function, e $\Delta \Phi$ (e is the electron charge, $\Delta \Phi$ is change of the electron extraction potential), of the catalyst under polarization. The change of the electron extraction potential has been measured to be equal to the applied polarization, i.e.

$$
\eta=\Delta \Phi
$$

It was also suggested that this change in the work function was caused by spillover of the products of the charge transfer from the three-phase boundary to the catalyst-gas interface. The change in the work function was measured using the Kelvin probe technique.

However, it has been found later ${ }^{18-22}$ that work function changes of catalyst with different morphology, measured using a Kelvin

\footnotetext{
* Electrochemical Society Active Member.

${ }^{\mathrm{z}}$ E-mail: njb@kemi.dtu.dk
}

probe, may be only a part of the applied polarization or do not change at all. Summarizing the results of Refs. 5-22, one can agree with the assumption of Emery et al. ${ }^{20}$ and Metcalfe ${ }^{21,22}$ that

$$
\Delta \Phi=\xi \eta
$$

where $\xi$ is a coefficient. Furthermore one can also assume $0 \leqslant \xi$ $\leqslant 1$.

The electrochemical potential of the electron in a metal, $\bar{\mu}_{\mathrm{e}}$ (Fermi level), is a sum of the chemical potential of the electron in the metal $\mu_{\mathrm{e}}$ and e $\phi$, where $\phi$ is the inner or Galvani potential. The Galvani potential is a sum of an outer (or Volta) potential, $\Psi$, and a surface potential, $\chi$. The work function of electron, $\mathrm{e} \Delta \Phi$, is equal to the electrochemical potential of the uncharged metal $(\Psi=0),{ }^{23}$ i.e.

$$
\Delta \Phi=\Delta \mu+\Delta \chi
$$

and $\Delta \Psi \neq 0$ is the reason for the difference between $\Delta \Phi$ and $\eta$ (Eq. 4). The value of $\xi$ is defined by the value of the polarization resistance of the electrochemical reaction at the catalyst support interface: if this resistance is low, $\xi \approx 1$; if this resistance is high, $\xi \approx 0$ and by polarization we mainly charge the catalyst-support electric double layer. ${ }^{20}$

In our previous paper ${ }^{2}$ we have defined three types of electrochemical promotion depending on values of the faradaic current $(I)$ and $\Lambda$, however it is more precise to separate electrochemical promotion and electrocatalysis.

1. The electrochemical promotion effect is the charge-induced change of the strength of chemisorptive bonds at the catalystsupport-reactant boundary in heterogeneous catalysis or electrodecatalyst interface in homogeneous catalysis (CI effect). The CI effect is characterized by $I=0, \eta=\Delta \Psi$, and $\Delta \Phi=0$. In this case the catalyst (or an electrode in homogeneous catalysis) is charged to the potential of the specific adsorption of one or more reactants.

2. The electrochemical promotion effect is the effect induced by the electrochemical production of the catalyst promoters (EPP effect). $I \neq 0 ; \Lambda \gg 1 ; \Delta \Psi=0$, and $\Delta \Phi=\eta$. The electrocatalytic effect is a separate case where the reactant (or reactants) of a catalytic reaction is (are) oxidized or reduced electrochemically, $I \neq 0, \Lambda \approx 1$.

Most published cases of electrochemical promotion $^{2-13}$ can be ascribed to the EPP effect or mixed CI and EPP effects, depending on the polarization resistance of the EPP reaction. The promotion of the homogeneous catalytic reaction ${ }^{1}$ or alkene isomerizations ${ }^{16}$ are examples of the CI effect. 


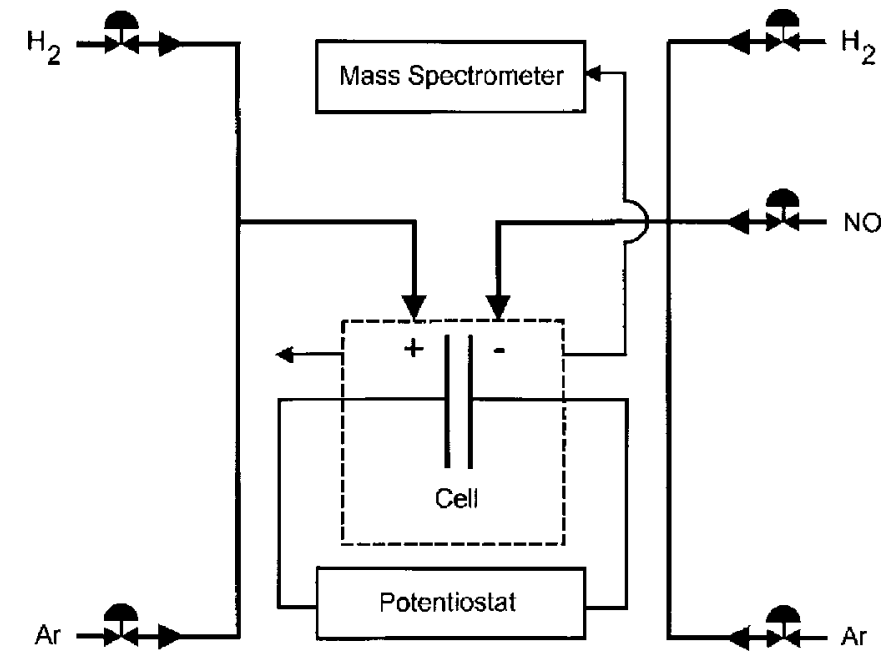

Figure 1. Setup for study of electrochemical promotion of catalytic reduction.

In most previous studies of electrochemical promotion of the catalytic NO reduction, Na was pumped to the surface of the catalyst using electrochemical reduction of $\mathrm{Na}^{+}$ions from $\mathrm{Na} \beta$ "-alumina support. ${ }^{11-14}$ This supply of Na greatly enhanced the reduction of $\mathrm{NO}$ on $\mathrm{Pt}, \mathrm{Pd}, \mathrm{Rh}$, and several other catalytic materials with a reaction rate enhancement as high as two orders of magnitude. Simultaneously the selectivity of production of $\mathrm{N}_{2}$ against $\mathrm{N}_{2} \mathrm{O}$ increased. Lambert et al. ${ }^{11-14}$ showed that the effect of electrochemical promotion is equivalent to the effect seen from depositing $\mathrm{Na}$ chemically on the catalyst surface. It means that the effect had a pure EPP nature.

The reason for NO reduction being promoted so remarkably is that the supply of $\mathrm{Na}$ to the catalytic surface changes the electronic properties of the surface. This happens in a way that strengthens the $\mathrm{N}$-catalyst bond at the expense of the $\mathrm{N}-\mathrm{O}$ bond, thereby facilitating the dissociation of $\mathrm{NO}$, which is the limiting step of the whole reaction. ${ }^{24}$ As $\mathrm{N}_{2} \mathrm{O}$ is produced by $\mathrm{NO}+\mathrm{N}($ ads $) \rightarrow \mathrm{N}_{2} \mathrm{O}$, the fast dissociation of $\mathrm{NO}$ diminishes the production of $\mathrm{N}_{2} \mathrm{O} \cdot{ }^{24}$

The electrochemical promotion of $\mathrm{NO}$ reduction is increased with the loading of $\mathrm{Na}$ until a certain point, where the supply of any more Na leads to a poisoning of the system. ${ }^{12}$ This poisoning happens because when too much $\mathrm{Na}$ is present, it and $\mathrm{O}_{\text {ads }}$ from the $\mathrm{NO}$ dissociation begin to cover most of the active centers blocking out new NO molecules.

Electrochemical promotion of $\mathrm{NO}$ reduction also took place when the catalyst support was an $\mathrm{O}^{2-}$ conducter. For this kind of system, an increase in $\mathrm{NO}$ reduction rate (up to $\Lambda=700$ ) was obtained when $\mathrm{O}^{2-}$ was removed from (or in some cases added to) the catalytic surface. $9,10,15,17$

In the present research the electrochemical promotion of catalytic NO reduction by hydrogen was studied using a

$$
\left\langle\left(\mathrm{NO}, \mathrm{H}_{2}, \mathrm{Ar}\right), \mathrm{Pt}\right| \text { polybenzimidazole }(\mathrm{PBI})-\mathrm{H}_{3} \mathrm{PO}_{4}\left|\mathrm{Pt},\left(\mathrm{H}_{2}, \mathrm{Ar}\right)\right\rangle
$$

fuel cell. ${ }^{25}$ Our purpose was to study the possibility of promoting NO reduction with the adsorbed hydrogen atoms produced electrochemically.

\section{Experimental}

The setup for study of electrochemical promotion of the catalytic NO reduction is given in Fig. 1. The carbon-supported Pt catalyst with Pt load around $0.5 \mathrm{mg} / \mathrm{cm}^{2}$ was used in this investigation. ${ }^{3}$ The electrolyte was $\mathrm{PBI}$ doped with $\mathrm{H}_{3} \mathrm{PO}_{4}$. The techniques of preparing the $\mathrm{PBI}\left(\mathrm{H}_{3} \mathrm{PO}_{4}\right)$ membrane electrolyte and the $\mathrm{Pt}, \mathrm{C} / \mathrm{PBI}$ $\left(\mathrm{H}_{3} \mathrm{PO}_{4}\right) / \mathrm{Pt}, \mathrm{C}$ assembly (the working electrode area is $5 \mathrm{~cm}^{2}$ ) were

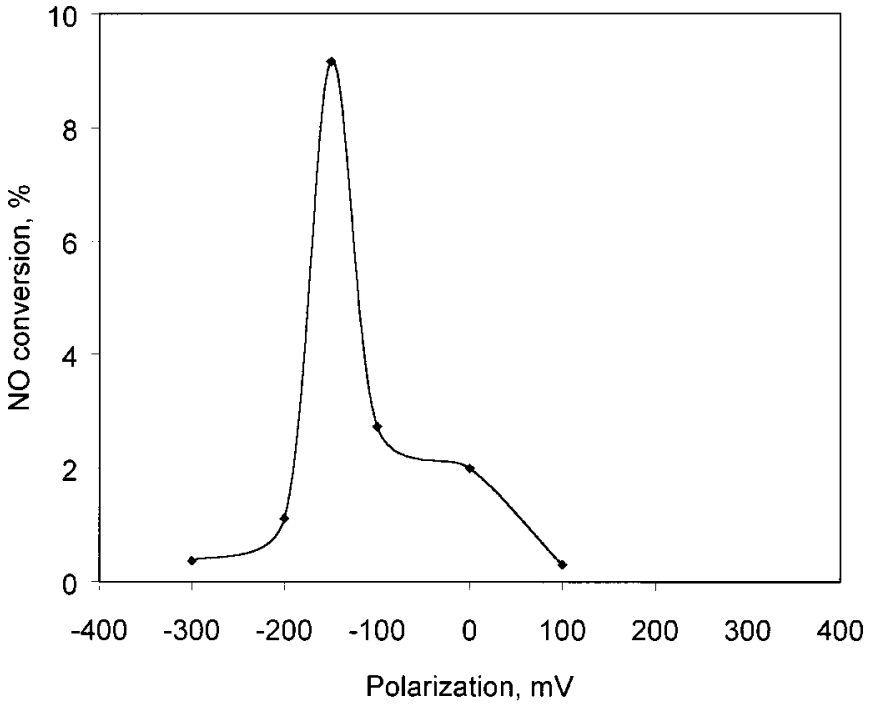

Figure 2. Dependence of $\mathrm{NO}$ conversion on polarization obtained in (NO, $\left.\mathrm{H}_{2}, \mathrm{Ar}\right)$, Pt/polybenzimidazole $(\mathrm{PBI})-\mathrm{H}_{3} \mathrm{PO}_{4} / \mathrm{Pt},\left(\mathrm{H}_{2}, \mathrm{Ar}\right)$ fuel cell at high $\mathrm{NO}+\mathrm{H}_{2}+$ Ar flow rate $(17 \mathrm{~mL} / \mathrm{min} ; 17$ and $354 \mathrm{~mL} / \mathrm{min}$, respectively, at atmospheric pressure) and at $135^{\circ} \mathrm{C}$.

developed in our group as well as by others. ${ }^{3}$ Graphite plates with gas channels were used as holders and current collectors. Two aluminum end plates with attached heaters were used to clamp the graphite plates. The temperature was controlled by a home-made controller. Mass flowmeters (5850 S Brookssmart) and 0154 Brooks Instrument controllers were used to control the inlet gas composition. The outlet gas composition was measured by an on-line quadrupole mass spectrometer (QMS 421, Pfeiffer) with a secondary electron multiplier detector and a cross-beam ion source with a rhenium filament. The ionization voltage was $70 \mathrm{~V}$. The outlet gases were admitted to the mass spectrometer from the fuel cell through an $0.8 \mathrm{~mm}$ stainless steel capillary.

The mixture of $\mathrm{NO}$ and hydrogen, diluted by $\mathrm{Ar}\left(\mathrm{NO} / \mathrm{H}_{2} / \mathrm{Ar}\right.$ $=17 \mathrm{~mL} / \mathrm{min} ; 17$ and $354 \mathrm{~mL} / \mathrm{min}$; or $17 \mathrm{~mL} / \mathrm{min} ; 17$ and 140 $\mathrm{mL} / \mathrm{min}$, respectively, at atmospheric pressure) was used as a working mixture at one electrode and hydrogen/argon mixture $\left(\mathrm{H}_{2} / \mathrm{Ar}\right.$ was 17 and $371 \mathrm{~mL} / \mathrm{min}$ or 17 and $140 \mathrm{~mL} / \mathrm{min}$, respectively) was used as a reference and a counter gas at the other electrode. The temperature was $135-137^{\circ} \mathrm{C}$.

Commercial gases NO $(99.9 \%), \mathrm{H}_{2}\left(99.9 \%, \leqslant 10 \mathrm{ppm}\right.$ of $\mathrm{O}_{2}$, $\leqslant 15$ ppm of $\left.\mathrm{H}_{2} \mathrm{O}\right)$, and $\mathrm{Ar}\left(<40 \mathrm{ppm} \mathrm{O}_{2}+\mathrm{H}_{2} \mathrm{O}\right)$ were used.

An EG\&G Instrument (Princeton Applied Research) 283 potentiostat/galvanostat controlled by 352 SoftCorr $^{\mathrm{TM}}$ III Software was used for electrode polarization and steady-state voltammetric measurements. The initial (at zero polarization) catalytic activity was measured after the yield of gas products had stabilized, i.e., under steady-state conditions. For each value of polarization the measurements were performed after stabilization of the yield of gas products (1-1.5 h). NO conversion vs. polarization curves were reproduced for each studied product and temperature. The open-circuit potential of the working electrode was approximately $0.14 \mathrm{~V}$.

\section{Results and Discussion}

The results of the investigation of the electrochemical promotion of the catalytic NO reduction are given in Fig. 2-5. The presented data has been obtained at high and low gas flow rates to create the conditions where there are, respectively, an underproduction and an overproduction of the $\mathrm{Pt}-\mathrm{H}_{\mathrm{ads}}$ and $\mathrm{Pt}-\mathrm{H}_{\mathrm{ads}}^{+}$sites at the catalyst-gas interface through the chemical reaction.

Data in Fig. 2 and 3 were obtained at high gas flow rate after the catalyst was first polarized $0.1 \mathrm{~V}$ positively and then negatively to 


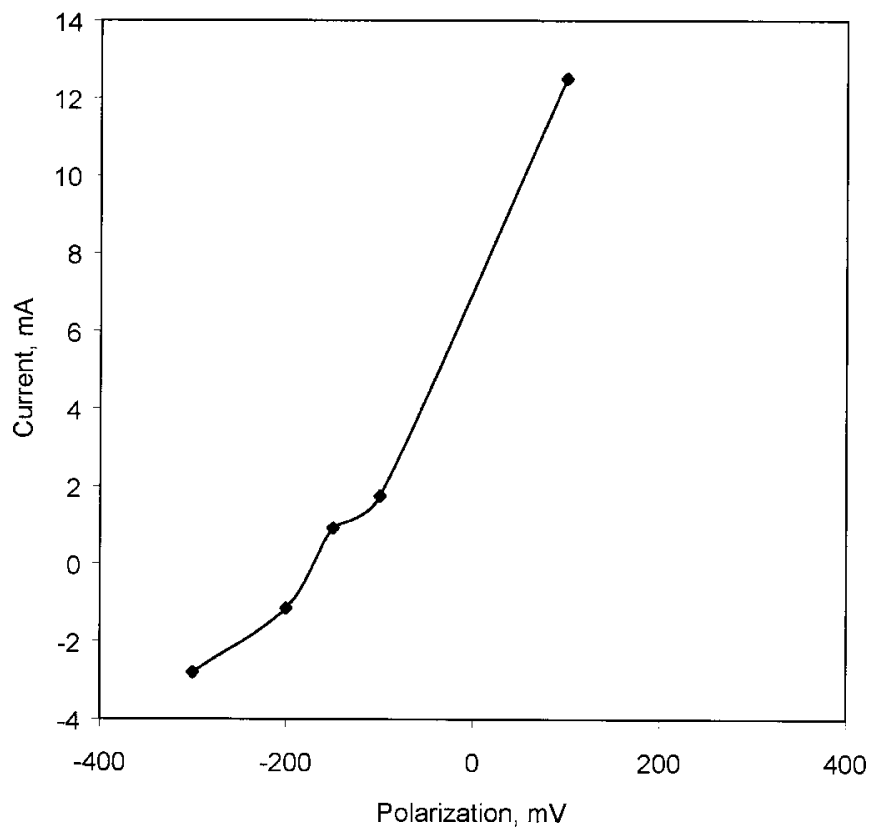

Figure 3. Steady-state voltammetric curve obtained at Pt catalyst at high $\mathrm{NO}+\mathrm{H}_{2}+$ Ar flow rate $(17 \mathrm{~mL} / \mathrm{min} ; 17$ and $354 \mathrm{~mL} / \mathrm{min}$, respectively, at atmospheric pressure) and at $135^{\circ} \mathrm{C}$.

$-0.3 \mathrm{~V}$. Nitrogen and water are the NO reduction products. Without polarization the NO conversion was $2 \%$ (Fig. 2). The reaction is assumed to be

$$
2 \mathrm{NO}+2 \mathrm{H}_{2} \rightarrow \mathrm{N}_{2}+2 \mathrm{H}_{2} \mathrm{O}
$$

Dependence of the NO conversion on polarization is given in Fig. 2. It can be seen that Reaction 6 can be electrochemically promoted at negative polarization and exhibits a clear "volcano"-type promotion behavior. ${ }^{6}$ This means that there is a maximum promotion effect (9.3\% NO conversion) at a polarization of approximately $-0.15 \mathrm{~V}$, or $-0.01 \mathrm{~V}$ catalyst potential vs. the reversible hydrogen electrode, RHE. The catalytic rate enhancement ratio at this maximum is 4.65 . Figure 2 shows no NO conversion at a polarization $\leqslant 0.1$ and $\leqslant-0.3 \mathrm{~V}$.

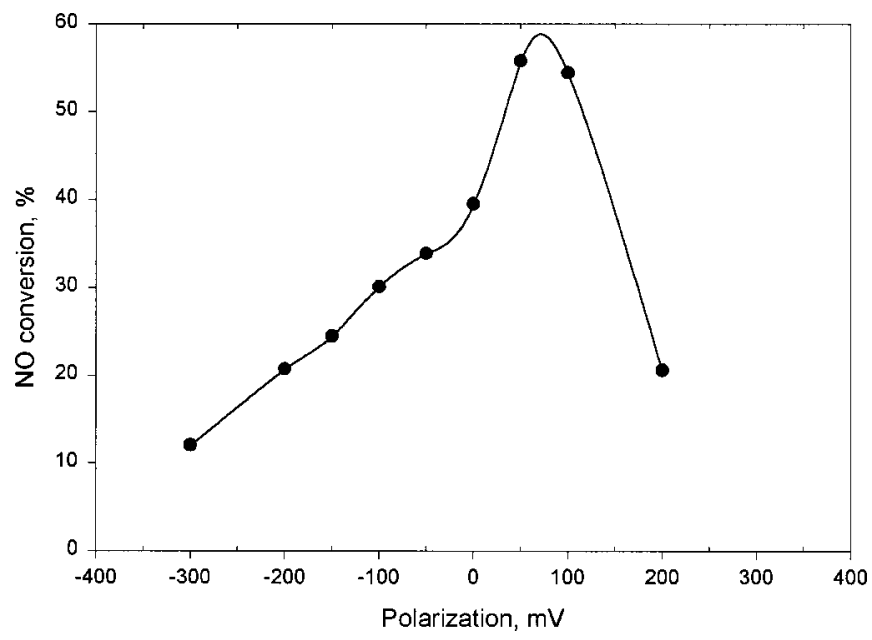

Figure 4. Dependence of NO conversion on polarization obtained in (NO, $\left.\mathrm{H}_{2}, \mathrm{Ar}\right), \mathrm{Pt} /$ polybenzimidazole $(\mathrm{PBI})-\mathrm{H}_{3} \mathrm{PO}_{4} / \mathrm{Pt},\left(\mathrm{H}_{2}\right.$, Ar) fuel cell at low $\mathrm{NO}+\mathrm{H}_{2}+$ Ar flow rate $(17 \mathrm{~mL} / \mathrm{min} ; 17$ and $140 \mathrm{~mL} / \mathrm{min}$, respectively, at atmospheric pressure) and at $135^{\circ} \mathrm{C}$.

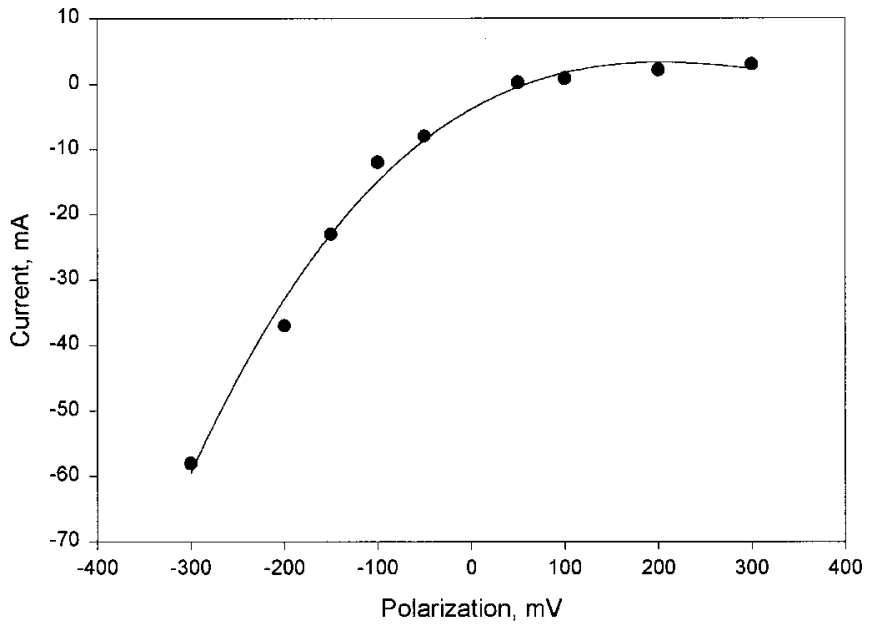

Figure 5. Steady-state voltammetric curve obtained at Pt catalyst at low $\mathrm{NO}+\mathrm{H}_{2}+$ Ar flow rate $(17 \mathrm{~mL} / \mathrm{min} ; 17$ and $140 \mathrm{~mL} / \mathrm{min}$, respectively, at atmospheric pressure) and at $135^{\circ} \mathrm{C}$.

There are obvious anodic and cathodic faradaic reactions inside this potential region (presence of the voltammetric waves, Fig. 3). The anodic current at the potential of maximum effect was 0.2 $\mathrm{mA} / \mathrm{cm}^{2}$. The value of $\Lambda$ calculated for the maximum promotion effect was $1.26 \times 10^{3}$, i.e., $\Lambda \gg 1$. This means that this effect has an EPP nature. ${ }^{2}$

The closest published example of an electrochemically promoted catalytic reaction is the catalytic oxidation of $\mathrm{CO}$ by $\mathrm{O}_{2}$ at the $\mathrm{Pt}$ catalyst on YSZ support. ${ }^{19}$ According to Belyaev et al., this catalytic reaction is promoted by $\mathrm{ZO}_{2}^{-}$oxygen species which are the products of the interaction between electrochemically produced $\mathrm{ZO}^{-}$species and chemically adsorbed oxygen species $\mathrm{Z}_{\mathrm{o}} \mathrm{O}$ (where $\mathrm{Z}$ are the catalyst active sites at the catalyst-support-gas interface and $Z_{0}$ are the catalyst active sites at the catalyst-gas interface). We can assume here that both electrochemically produced $\mathrm{ZH}$ and chemically produced $\mathrm{Z}_{\mathrm{o}} \mathrm{H}$ species, and also the possible product of their interaction with $\mathrm{H}^{+}, \mathrm{ZH}_{2}^{+}$, can promote the NO catalytic reduction. The reaction

$$
\mathrm{ZH} \rightleftharpoons \mathrm{Z}+\mathrm{H}^{+}+\mathrm{e}
$$

takes place in the potential range between 0 and $0.4 \mathrm{~V} v s$. RHE, ${ }^{25}$ i.e., at the potentials of the electrochemical promotion of NO reduction (Fig. 2). The nature of promotion of NO reduction by the adsorbed hydrogen species is probably the same as the nature of the promotion of the same reaction by the adsorbed $\mathrm{Na}$ atoms. ${ }^{11-14}$ It has been shown that the rate-determining step of the catalytic NO reduction at a Pt catalyst is dissociative chemisorption of NO because $\mathrm{Pt}$ is relatively ineffective at this step. ${ }^{24}$ Adsorbed hydrogen species can act to increase the adsorption strength of electronegative adsorbates (NO) and weaken the $\mathrm{N}-\mathrm{O}$ bond in the adsorbed molecule and therefore promote NO dissociation. ${ }^{13}$

Data in Fig. 4 and 5 were obtained at low gas flow rate after the catalyst was first polarized $-0.3 \mathrm{~V}$ negatively and then positively to $0.2 \mathrm{~V}$. It can be seen from comparison of Fig. 2 and 4 that NO reduction is increased 20 times even without polarization. Moreover, under these conditions negative polarization decreased the rate of NO reduction (i.e., an opposite effect to what was found at high gas flow rates). It can also be seen that the electrochemical promotion effect did occur at a positive polarization with maximum increase at approximately $0.08 \mathrm{~V}$ polarization and with 1.5 times the zero polarization value.

The steady-state voltammetric behavior of the catalyst at a low gas flow rate is shown in Fig. 5. It is obvious from Fig. 5 that in the potential range of the promotion effect faradaic current is absent. 
This means that the promotion effect has a CI nature. ${ }^{2}$ Increase of the NO conversion under open-circuit conditions and changes in the nature of the promotion effect can be explained by a high concentration of Pt-H sites at the low gas flow rates. The increased number of the adsorbed hydrogen species (as in the NO promotion with $\mathrm{Na}^{12,24}$ ) can complicate the NO (electronegative adsorbate) chemisorption, especially at negative polarization. At positive polarization, however, the charge-induced change of the strength of chemisorptive bonds can take place (CI effect).

\section{Conclusions}

The possibility of the electrochemical promotion of the catalytic $\mathrm{NO}$ reduction by hydrogen at the Pt-PBI $\left(\mathrm{H}_{3} \mathrm{PO}_{4}\right)$-gas boundary has been demonstrated. It has also been shown that the nature of this promotion effect can vary depending on the flow rate of the $\mathrm{NO} / \mathrm{H}_{2} /$ Ar gas mixture. At high $\mathrm{NO}+\mathrm{H}_{2}+$ Ar flow rate $(17 \mathrm{~mL} /$ min; 17 and $354 \mathrm{~mL} / \mathrm{min}$, respectively, at atmospheric pressure), it has been found that NO reduction can be electrochemically promoted at negative polarization with maximum at approximately $-0.15 \mathrm{~V}$, i.e., close to the potential found for the maximum promotion of $\mathrm{CH}_{4}$ oxidation at the same catalyst. ${ }^{2}$ The maximum rate enhancement ratio was 4.65 . The value of $\Lambda$ calculated for maximum promotion effect conditions was $1.26 \times 10^{3}$, i.e., $\Lambda \gg 1$. This means that this effect has an EPP nature, the catalytic reaction was promoted by the electrochemically produced adsorbed hydrogen species.

At low $\mathrm{NO}+\mathrm{H}_{2}+$ Ar flow rate $(17 \mathrm{~mL} / \mathrm{min} ; 17$ and $140 \mathrm{~mL} /$ min, respectively, at atmospheric pressure), NO reduction increased 20 times even without polarization. Moreover, under these conditions negative polarization decreased the rate of $\mathrm{NO}$ reduction (i.e., an opposite effect to what was found at high gas flow rates). However, the electrochemical promotion effect did occur at positive polarization with maximum increase at approximately $0.08 \mathrm{~V}$ and with 1.5 times the zero polarization value. In the potential range of the promotion effect faradaic current is absent. It means that the promotion effect has a CI nature. This means that the effect was caused by the charge-induced change of the strength of chemisorptive bonds.

\section{Acknowledgments}

This investigation has been supported by the PSO-F\&U contract no. 3089 and by the Danish Research Councils ICAT project no. 9702636.
Technical University of Denmark assisted in meeting the publication costs of this article.

\section{References}

1. I. M. Petrushina, V. A. Bandur, F. Cappeln, N. J. Bjerrum, J. Electrochem. Soc., 147, 3010 (2000).

2. I. M. Petrushina, V. A. Bandur, N. J. Bjerrum, F. Cappeln, and Q. Li, J. Electrochem. Soc., 149, D143 (2002).

3. Q. Li, H. A. Hjuler, and N. J. Bjerrum, J. Appl. Electrochem., 31, 773 (2001).

4. C. Wagner, Adv. Catal., 21, 323 (1970)

5. C. G. Vayenas, S. Bebelis, and S. Ladas, Nature (London), 343, 625 (1990).

6. C. G. Vayenas, S. Bebelis, C. Pliangos, S. Brosda, and D. Tsiplakides, Electrochemical Activation of Catalysis: Promotion, Electrochemical Promotion and Metal-Support Interactions, Kluwer Academic/Plenum Publishers, New York (2001).

7. C. G. Vayenas and S. Bebelis, Catal. Today, 51, 581 (1999).

8. S. Bebelis, M. Makri, A. Buekenhoudt, J. Luyten, S. Brosda, P. Petrolekas, C. Pliangos, and C. G. Vayenas, Solid State Ionics, 129, 33 (2000).

9. C. Pliangos, C. Raptis, Th. Badas, D. Tsiplakides, and C. G. Vayenas, Electrochim. Acta, 46, 331 (2000).

10. C. Pliangos, C. Raptis, Th. Badas, D. Tsiplakides, and C. G. Vayenas, Solid State Ionics, 136-137, 767 (2000).

11. R. M. Lambert, A. Palermo, F. J. Williams, and M. S. Tikhov, Solid State Ionics, 136-137, 677 (2000).

12. I. V. Yentekakis, M. Konsolakis, R. M. Lambert, A. Palermo, and M. Tikhov, Solid State Ionics, 136-137, 783 (2000).

13. N. Macleod, J. Isaac, and R. M. Lambert, J. Catal., 198, 128 (2001).

14. F. J. Williams, A. Palermo, M. S. Tikhov, and R. M. Lambert, J. Phys. Chem. B, 105, 1381 (2001)

15. G. Fóti, O. Lavanchy, and C. Comminelis, J. Appl. Electrochem., 30, 1223 (2000).

16. L. Ploese, M. Salazar, B. Gurau, and E. S. Smotkin, Solid State Ionics, 136-137, 713 (2000).

17. S. Kim and G. L. Haller, Solid State Ionics, 136-137, 693 (2000).

18. J. Poppe, S. Völkening, A. Schaak, E. Schütz, J. Janek, and R. Imbihl, Phys. Chem. Chem. Phys., 1, 5241 (1999).

19. V. D. Belyaev, T. I. Politova, and V. A. Sobyanin, Solid State Ionics, 136-137, 721 (2000).

20. D. A. Emery, R. J. C. Luke, P. H. Middleton, and I. S. Metcalfe, J. Electrochem. Soc., 146, 2188 (1999).

21. I. S. Metcalfe, J. Catal., 199, 247 (2001).

22. I. S. Metcalfe, J. Catal., 199, 259 (2001).

23. R. B. Anderson, Experimental Methods in Catalytic Research, Academic Press, New York (1968)

24. R. I. Masel, Catal. Rev. Sci. Eng., 28(2\&3), 335 (1986).

25. S. K. Zecevic, J. S. Wainright, M. H. Litt, S. Lj. Gojkovic, and R. F. Savinell, J. Electrochem. Soc., 144, 2973 (1997). 